\title{
A Morphological Study of the Dorsum Sellae in Human Skull
}

\author{
Estudio Morfológico del Dorsum Sellae en el Cráneo Humano
}

Syed Javed Haider; ; Assad Ali Rezigalla** \& Asim Mohammed Abdalla*

HAIDER, S. J.; REZIGALlA, A. A. \& ABDALlA, A. M. A morphological study of the dorsum sellae in human skull. Int. J. Morphol., 34(4):1187-1190, 2016.

SUMMARY: Anatomical variations in the shape and dimension of the dorsum sellae and posterior clinoid process are common. Most textbooks describe its shape as a median rectangular plate, a square plate, or a transverse ledge on a slope behind the sella turcica (hypophyseal fossa). This work aims to study the dorsum sellae of human skull. One hundred and twenty five dried adult human skulls, irrespective of age, were used for the study. Detailed features of the dorsum sellae were noted and classified into five types: crest like, thin plate, frail quadrilateral plate, heavy square plate, thick elongated plate. Fusion of the posterior and middle clinoid processes in one (unilateral) and all the clinoid processes (anterior, middle, and posterior) in three skulls (unilateral in one, bilateral in two) were also noticed. Findings are discussed in the light of the literature.

KEY WORDS: Dorsum sellae; Clinoid process; Anatomical variations; Skull.

\section{INTRODUCTION}

The dorsum sellae is an important bony entity in the posterior cranial fossa of the human skull due to its close proximity and relationship with hypophyseal fossa, brain stem and emerging cranial nerves. Various standard anatomical text books have given different morphological appearance and shape to the dorsum sellae. It has been described as median rectangular (Grant et al., 1989), slope (Lang, 2001) and transverse ledge like (Sinnatamby, 2011). Standring et al. (2005) mentions it as square plate like behind the hypophyseal fossa, ending superolaterally into posterior clinoid processes. Salma et al. (2011) reported absence of the dorsum sellae and the posterior clinoid process. One detailed morphological study has described the dorsum sellae as a raised plate with no demarcated posterior clinoid processes in the majority of skulls (Halim, 1981). Abnormal pyramidal dorsum sellae and other irregularities like notching in its posterior wall have also been reported (Axelsson et al., 2004). Considering the above varied description regarding the shape and dimension of the dorsum sellaee, and thact that it affects the depth of the hypophyseal fossa this work on its morphology has been undertaken.

\section{MATERAL AND METHOD}

The study was conducted on 125 dried human skulls obtained from the anatomy departments of College of Medicine, King Khalid University, Abha, Kingdom of Saudi Arabia, and J. N. Medical College, Aligarh Muslim University, Aligarh, India. Sex was not taken into consideration but the skulls of extreme age were avoided. Hypophyseal fossa and the adjoining areas were cleaned with swab dipped in alcohol. Detailed features of the dorsum sellae and the posterior clinoid processes were noted and classified into five types as specified in the results. Any fusion of the posterior with anterior or middle clinoid processes was also noticed.

\section{RESULTS}

The common variations of the dorsum sellae and the posterior clinoid processes were classified into five types as below:

Type I. Crest like without any indication of the posterior clinoid processes.

\footnotetext{
* Department of Anatomy, College of Medicine, King Khalid University, Saudi Arabia.

*"Department of Anatomy, College of Medicine, University of Bisha, Saudi Arabia.
} 
Type II. Thin plate without any indication of the posterior clinoid processes.

Type III. Frail quadrilateral plate with small posterior clinoid processes.

Type IV. Heavy square plate with well-developed posterior clinoid processes.

Type V. Thick elongated plate raised above the anterior clinoid processes.

The frequency of the above types is given in Table I. Unilateral fusion of the posterior with middle clinoid process (unilateral) was found in one skull, and fusion of the three clinoid processes was found in three skulls, unilateral in one and bilateral in two.

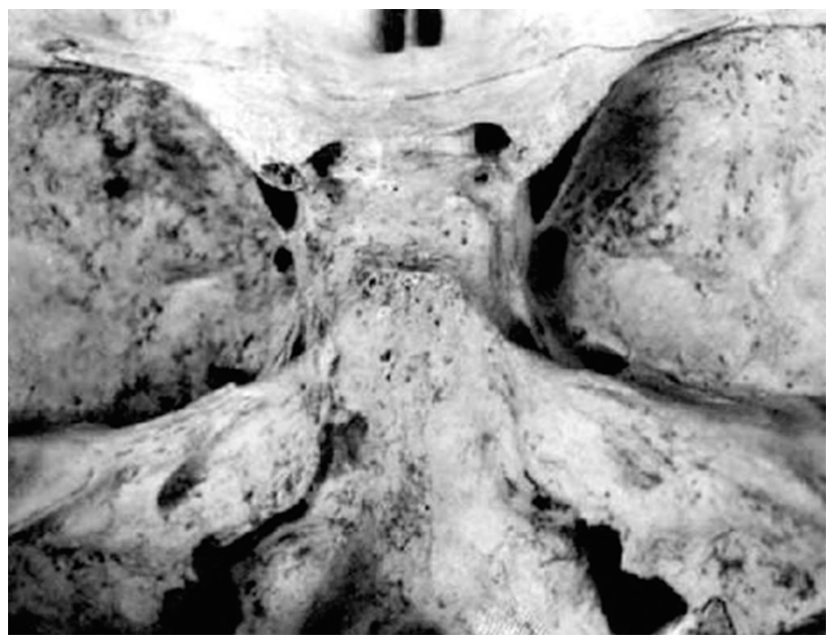

Fig. 1. Middle cranial fossa with crest like dorsum sellae without posterior clinoid processes.

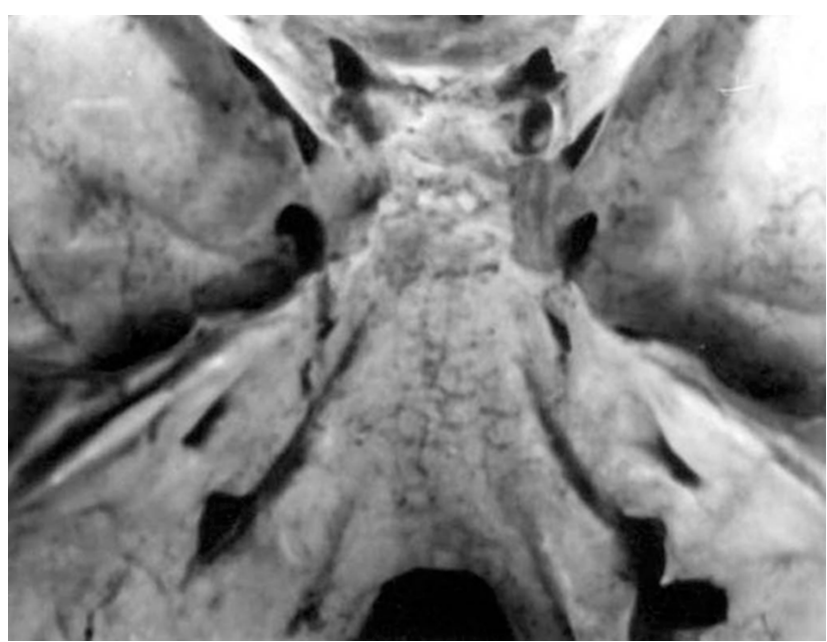

Fig. 2. Middle cranial fossa with thin plate like dorsum sellae without posterior clinoid processes.

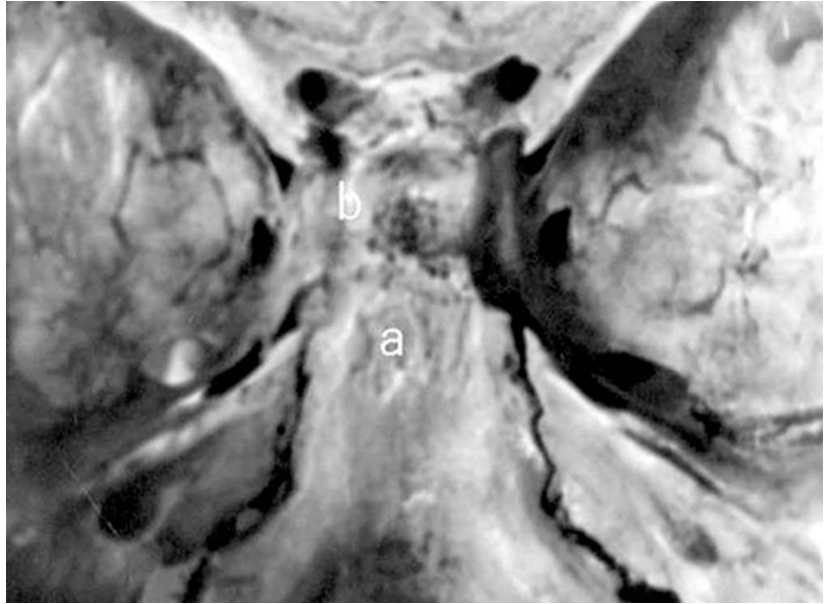

Fig. 3. Middle cranial fossa with (a) frail quadrilateral plate like dorsum sellae with small posterior clinoid processes and (b) unilateral fusion (left side) of the middle and posterior clinoid processes.

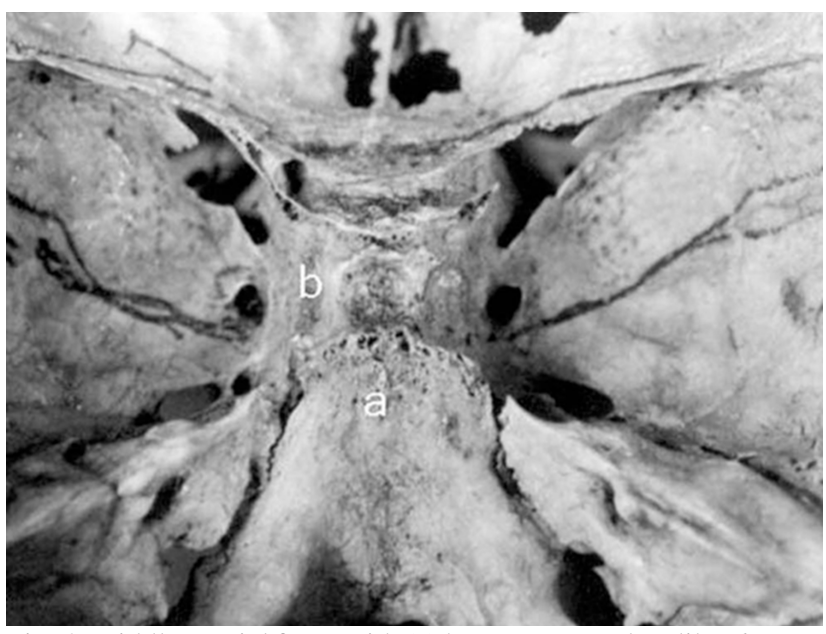

Fig. 4. Middle cranial fossa with (a) heavy square plate like dorsum sellae with well-developed posterior clinoid processes and (b) bilateral fusion of all the clinoid processes.

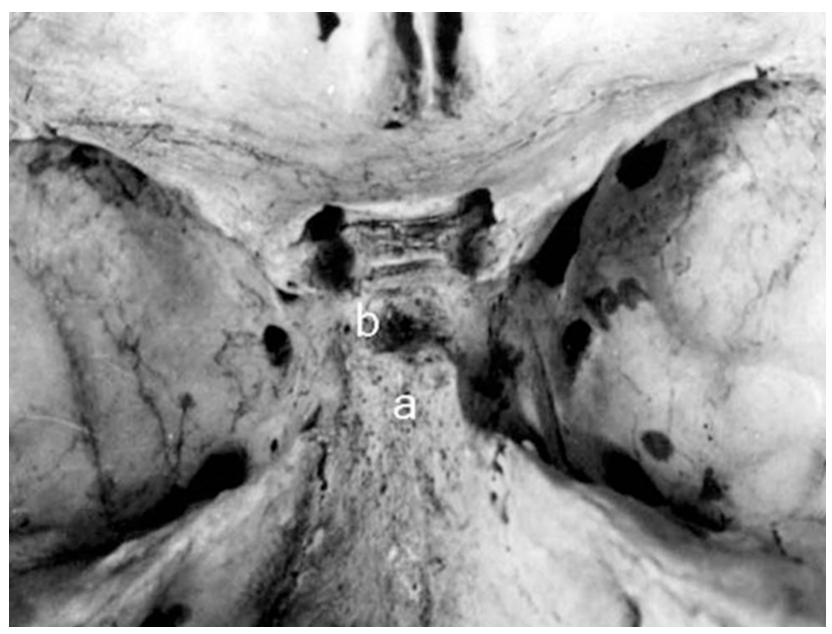

Fig. 5. Middle cranial fossa with (a) thick elongated plate like dorsum sellae raised above the anterior clinoid processes and (b) unilateral fusion (left side) of all the clinoid processes. 
Table I. Incidence and details of the various types of dorsum sellae and clinoid processes; ACP: anterior clinoid processes; PCP: posterior clinoid processes.

\begin{tabular}{cccl}
\hline Type & No. of Skulls & Percentage $\%$ & \multicolumn{1}{c}{ F eatures of dorsum sella } \\
\hline I & 07 & 5.60 & Crest like without PCP \\
II & 53 & 42.40 & Thin plate without PCP \\
III & 48 & 38.80 & Frail quadrilateral with small PCP \\
IV & 12 & 9.60 & Heavy square plate with well-developed PCP \\
V & 5 & 4.00 & Thick elongated plate raised above the ACP. \\
\hline
\end{tabular}

\section{DISCUSSION}

The frequency of frail quadrilateral plate dorsum sellae, with small posterior clinoid process found here $(38.4$ $\%$ ) is higher than that previously reported, whereas the incidence of the other categories is in substantial agreement with previous reports (Halim). Absence of dorsum sellae (as described by Salma et al.) has not been observed here. Unilateral fusion of the posterior and middle clinoid processes was seen in one skull. Fusion of all the three clinoid processes (anterior, middle, and posterior) was found in three skulls, giving raise to a 'bridge sella'. Salma et al. had reported the same result with single unilateral and double bilateral fusion of the clinoid processes. This situation may be explained by the ossification of the fibrous bands connecting the clinoid processes (Kolagi et al., 2011). Kolagi et al. with approximately the same sample size, reported a high incidence of sella turcica bridges and found that the number of unilateral bridges was double that of bilateral ones.

Usually, no serious clinical threat has been described to be associated with above anatomical variations of the dorsum sellae and the posterior clinoid processes (Paul \& Das, 2007; Salma et al.). However, it has been suggested that a very large and prominent posterior clinoid process with thick plate dorsum sellae may stretch the neighboring cranial nerves especially the common oculomotor nerve, by displacing the brain stem backward (Joseph et al., 1979). This will produce signs and symptoms according to the nerve involved.
Varying height of the dorsum sellae was observed to be directly responsible for determining the depth of the $s e$ lla turcica. Its neighboring region and hypophyseal fossa are relevant for radiological diagnosis and the clinics. Early local lesions such as outgrowth from the pituitary gland or a generalized disorder producing high intracranial tension greatly change the shape and dimension of sella turcica and thereby that of dorsum sellae. Tumors of the pituitary gland may push the dorsum sellae backward. Enlargement of the brain ventricles, especially of the third ventricle, as seen in hydrocephalic children may exert pressure, causing thinning of the dorsum sellae. Moreover, bony formation resulting into fusion of clinoid processes may interfere with the normal course of nerves or vascular structures, mainly the internal carotid artery, presenting with bizarre clinical symptoms. Therefore, the various morphological features of the dorsum sellae and adjoining region are of clinical relevance.

\section{ACKNOWLEDGEMENTS}

The authors are grateful to Dr. Nafis A. Faruqi, Chairman, Department of Anatomy, J. N. Medical College, Aligarh Muslim University Aligarh, India, for allowing the use of the skull collection for this work. The authors also appreciate and thank Mr. Elhaj Abbas Elhaj for technical help in images.

HAIDER, S. J.; REZIGAlLA, A. A. \& ABDALLA, A. M. Estudio morfológico del dorsum sellae en el cráneo humano. Int. J. Morphol., 34(4):1187-1190, 2016.

RESUMEN: Son frecuentes las variaciones anatómicas de la forma y dimensión de dorsum sellae y de los procesos clinoides posteriores. La mayoría de los textos describen su forma como una placa rectangular mediana, una placa cuadrada, o un plano transversal en una pendiente detrás de la sella turcica (fosa hipofisaria). Este trabajo tiene como objetivo estudiar el dorsum sellae en cráneo humano. Para el estudio se utilizaron 125 cráneos humanos adultos secos, de diferentes edades. Se observaron características detalladas de dorsum sellae y se clasificaron en cinco tipos: cresta, al igual que la placa delgada, lámina cuadrilátera, placa cuadrada gruesa, placa alargada gruesa. En tres cráneos se observó fusión de la parte posterior y los procesos clinoides intermedios (unilateral) y los procesos clinoides (anterior, medio y posterior) (unilateral en uno de ellos, bilateral en dos). Los resultados se discuten en consideracion de la literatura.

PALABRAS CLAVE: Dorsum sellae; Proceso clinoides; Variaciones anatómicas; Cráneo. 


\section{REFERENCES}

Axelsson, S.; Storhaug, K. \& Kjaer, I. Post-natal size and morphology of the sella turcica. Longitudinal cephalometric standards for Norwegians between 6 and 21 years of age. Eur. J. Orthod., 26(6):597-604, 2004.

Grant, J. C. B.; Basmajian, J. V. \& Slonecker, C. E. Grant's Method Of Anatomy: A Clinical Problem-Solving Approach. $11^{\text {th }}$ ed. Baltimore, Williams \& Wilkins, 1989. pp.523-5.

Halim, A. Some observations on the dorsum sellae. J. Anat. Soc. India, 3:41-5, 1981.

Joseph, B.; Bisaria, K. K. \& Halim, A. The relationship between the third cranial nerve and posterior clinoid process. Indian $J$. Ophthalmol., 26(4):81-22, 1979.

Kolagi, S.; Herur, A.; Patil, G. \& Rairam, G. B. Complete sella turcica bridges prevalence and dimensions. J. Anat. Soc. India, 60(1):22-5, 2011.

Lang, J. Skull Base and Related Structures: Atlas of Clinical Anatomy. Stuttgart, Schattauer, 2001. pp.172-4.

Paul, S. \& Das, S. Anomalous posterior clinical process and its clinical importance. Colomb. Med., 38(3):301-4, 2007.

Salma, A.; Baidya, N. B.; Wendt, B.; Aguila, F.; Sammet, S. \& Ammirati, M. Qualitative and quantitative radio-anatomical variation of the posterior clinoid process. Skull Base, 21(6):3738,2011

Sinnatamby C. Last's Anatomy: Regional and Applied. $12^{\text {th }}$ ed. Edinburgh, Churchill Livingstone/Elsevier, 2011. pp.508-9.

Standring, S. Gray's Anatomy. The Anatomical Basis of Clinical Practice. $39^{\text {th }}$ ed. Edinburgh, Elsevier, 2005. pp.465.
Correspondence to: Assad Ali Rezigalla

College of Medicine

University of Bisha, Abha

Kingdom of Saudi Arabia

SAUDI ARABIA

Email: assadkafe@yahoo.com

Received: 19-03-2016

Accepted: 02-08-2016 